\title{
OPTIMAL POLICY TOWARDS FAMILIES WITH DIFFERENT AMOUNTS OF SOCIAL CAPITAL, IN THE PRESENCE OF ASYMMETRIC INFORMATION AND STOCHASTIC FERTILITY
}

\author{
ALESSANDRO CigNO \\ ANNALISA LUPORINI
}

CESIFO WORKING PAPER NO. 1664 CATEgORY 1: Public FinANCE

FEBRUARY 2006

An electronic version of the paper may be downloaded

- from the SSRN website:

www.SSRN.com

- from the CESifo website: www.CESifo-group.de 


\title{
OPTIMAL POLICY TOWARDS FAMILIES WITH DiFFERENT AMOUNTS OF SOCIAL CAPITAL, IN THE PRESENCE OF ASYMMETRIC INFORMATION AND STOCHASTIC FERTILITY
}

\begin{abstract}
We examine the effects of differences in social capital on first and second best transfers to families with children, in an asymmetric information context where the number of births, and the future earning capacity of each child that is born, are random variables. The probability that a couple has children is conditional on the level of reproductive activity undertaken. The probability that a child will have high earning ability is positively conditioned not only by the level of educational investment undertaken by the child's parents, but also by the social capital of the latter. The optimal policy includes two transfers, one conditional on number of births, the other on the children's earning ability.
\end{abstract}

JEL Code: D13, D78, D82, H31, J13.

Keywords: education, stochastic fertility, child benefits, pensions, scholarships, social capital, asymmetric information, multi-agency.

\author{
Alessandro Cigno \\ University of Florence \\ Faculty of Political Science \\ Via delle Pandette 21 \\ 50127 Florence \\ Italy \\ cigno@unifi.it
}

\author{
Annalisa Luporini \\ University of Florence \\ Faculty of Political Science \\ Via delle Pandette 21 \\ 50127 Florence \\ Italy \\ annalisa.luporini@unifi.it
}

Paper to the 2003 CESifo Venice Summer Institute. The paper has benefited from comments by Firouz Gahvari, and by two anonymous referees. 


\section{Introduction}

Given that the number and well-being of future adults is conditioned by actions taken by their parents, is there any reason why the government should try to influence those actions? There are two lines one can take. One is to grant citizenship to potential as well as actual human beings. The other is to recognize as citizens only persons who actually exist. If one takes the first line, the usual equity-efficiency arguments for public intervention apply not only to actual, but also to potential human beings. If one takes the second line, these arguments apply only to actual persons, and imply that a policy is desirable only if it increases the welfare of the latter. Potential persons then matter only insofar and inasmuch as, for altruistic or egoistic reasons, their parents have their well-being at heart. Given the philosophical difficulties involved in treating individuals who may or may not come into being and whose characteristics are uncertain on a par with actual persons (Broome, 1993), that is the line we shall take in the present paper.

The questions we pose here have been addressed many times before in the literature, ${ }^{1}$ but the authors (present ones included) addressing them make one or both of two questionable assumptions. One is that parental actions (e.g., educational investment) affecting the productivity or, more generally, the welfare of future adults are observable by the government. This assumption ignores the fact that certain dimensions of parental activity are either impossible or extremely costly for a public authority to monitor, and that a public subsidy intended for children could thus end up as consumption for their parents. Even if parents are altruistic towards their children, convexity of preferences does in fact imply that any increase in family income, whatever its source, will increase expenditure on all normal goods, including parental consumption.

The other questionable assumption concerns fertility determination. Some papers assume that fertility is exogenous, others that it is perfectly controlled by parents. Both extremes are unrealistic, and may lead to incorrect policy prescriptions. Ignoring the fertility incentive effect of child related subsidies will in fact lead the policy maker to overlook the possibility that a policy intended to relieve child poverty might have the opposite effect. The opposite assumption, that parents can directly choose how many children to have, makes the action of procuring a certain number of births coincide with the outcome. Since the latter is observable, this assumption carries the distasteful implication that the government can costlessly dictate how many children a couple should

\footnotetext{
${ }^{1}$ For a survey, see Cigno (2005).
} 
have by threatening a sufficiently large penalty if they do not. ${ }^{2}$

Our starting point is Cigno, Luporini and Pettini (2003), where it is assumed that the number of children is deterministically chosen by parents, but a child's future earning capacity is a random variable with given density conditional on an unobservable parental action. Parents are taken to be identical. Since the government will eventually observe the earning capacity of children, but cannot observe the parental action that conditioned it, and given that this action cannot be inferred from the outcome, because the latter is partly the effect of chance, the model has a principal-agent structure with the government in the role of principal, and potential parents in that of agents.

In that paper, the justification for government intervention is that (i) atomistic parents do not fully internalize the social benefit of producing future tax payers, and enhancing their earning capacity, (ii) unlike parents, the government does not face any risk, because the number of present and future tax payers is assumed large. Point (ii) does not require much elaboration. Point (i) relates to one of the questions left unanswered by the optimum population literature, ${ }^{3}$ namely whether there is a population externality, and the nature of the externality. Many of the arguments used in this literature refer to general equilibrium effects that do not apply in the partial equilibrium setting adopted by the paper in question. In that paper as in the present one, the only possible externalities are fiscal. Atomistic parents have no reason to consider the effects of their reproductive behaviour, and of their educational investments, on future government revenue. This gives rise to two positive externalities, one concerning the number, the other the earning capacity of future tax payers.

All of that remains true in the present paper, but we extend the analysis in two important directions. One is to drop the assumption of perfect fertility control. We now treat the number of births as a random variable, with given density conditional on the reproductive behaviour of potential parents (the same is done by Cremer, Gahvari and Pestieau in another chapter of the present volume). We assume, in other words, that what parents-to-be can choose is not the actual number of children, but the probability of having $0,1,2, \ldots$ children. Since reproductive behaviour, unlike the number of births, is clearly not observable by the government, the latter cannot oblige parents to have any specified num-

\footnotetext{
${ }^{2}$ In principal-agent language, this is called a "forcing contract", and can be applied whenever an action is observable (or inferrable) by the principal. In a population policy context, it has a sinister ring.

${ }^{3}$ See Eckstein and Wolpin (1985), Michel and Pestieau (1993), Peters (1995), Razin and Sadka (1995), and Sinn (2004).
} 
ber of children. This gives rise to a moral hazard problem, analogous to the one associated with the non observability of educational investment. The other extension is to assume that parents differ in their ability to influence their children's probability of success in life. This introduces a redistributive motive for public intervention, in addition to those associated with externality and insurance considerations.

In reality, differences in parental ability to influence a child's probability of success may reflect differences in a variety of parental characteristics. An obvious one is parental income. If it is not possible to borrow against a child's expected future earnings, rich parents will tend to invest more than poor ones in their children's education. Since a child's education does not begin and end at school, another obviously relevant characteristic is parental ability to instill in their children the pleasure of learning, work ethics, etc. Differences in this kind of ability will lead to differences in the marginal cost of providing a child with any given level of earning capacity. The effects of differences in parental income on the design of policy are examined by Cremer, Dellis and Pestieau (2003) in an exogenous fertility setting. Those of ability to produce earners versus ability to earn are examined by Balestrino, Cigno and Pettini (2002) and Cigno, Luporini and Pettini (2004), the former in an optimal taxation, the latter in a principal-agent framework, but both under the assumption of deterministic fertility choice. Ability to earn and ability to educate children are dimensions of parental human capital. Here, we focus on another differentiating parental characteristic, social capital, and examine its so far unexplored fiscal implications.

At least since Stigler (1962), economists have been aware of the value of information regarding career opportunities. Social networks appear to be an important source of this kind information. Granovetter (1991) reports that as much as half the jobs are allocated through them. But, information is not all that social networks provide. Durlaf (2001) puts forward a "memberships theory of poverty", according to which a child whose parents belong to an underprivileged social group "grows up in a poor community whose role models and peer groups militate against economic success, and subsequently finds himself in a series of poor schools and jobs". In a context where the areas of residence are not rigidly segregated according to income and social status, the term "community" need not have a geographical connotation. Irrespective of place of residence, children of professional parents are in fact likely to have friends who spend many hours a day doing their homework. The opportunitycost of education is likely to be lower for children with this kind of peer group than for the rest. When they grow up, children of this kind are also more likely to have the information and personal connections that 
will help them to get a good job, and to advance in their career.

This interactions-based approach to modelling social influences on individual behaviour lends operational content to the otherwise elusive concept of social capital. In the present paper, we assume that parents differ in their endowment of this kind of capital. Allowing parents to differ also in some dimension of their human capital would not make any qualitative difference if this were either uncorrelated, or positively correlated with social capital. It would make a difference if the correlation were negative, but that does not seem very plausible where the earning ability dimension of human capital is concerned. We shall further assume that social capital is positively correlated with visible parental characteristics such as occupation, and perhaps place of residence, and that it is thus inferable by the government.

Our modelling strategy bears similarities to the Principal MultiAgent approach of Holmström (1982), but we depart from this author in two, not entirely secondary, respects. First, we do not assume that the interests of the principal are diametrically opposed to those of the agents (in our model, the government maximizes the sum of the objective functions of the parents). Second, our model has a dynamic programming structure. The (privately and the socially) optimal choice of reproductive behaviour is determined by backward induction, after solving for the (privately and the socially) optimal educational investment conditional on number of children actually born.

\section{The model}

To simplify matters, we assume that there are only two types of parents, $A$ or $B$, and many couples of each type (otherwise, they could collude to influence government policy). The former are "more productive" than the latter in the precise sense that, for any amount of formal and informal education imparted on a child, the cumulative probability that the variable representing the child's economic success does not exceed a certain value is everywhere higher if the parents are of type $B$, than if they are of type $A$. We attribute this difference to the fact that type $A$ has more social capital than type $B$.

This does not imply that a child of type- $B$ parents cannot do better than a child of type- $A$ parents, but it does imply that, for any given level of parental investment in the child's education, the expectation of success is higher for the latter than for the former. ${ }^{4}$ Assuming that the

\footnotetext{
${ }^{4}$ A type- $B$ couple could turn itself into an $A$ by investing in its own education, or changing place of residence. But changing type absorbs parental resources that could otherwise be invested in children. Therefore, the initial status of the parents unavoidably conditions the chances of success of the children. We shall assume that
} 
amount a person pays in taxes over a lifetime increases monotonically with that person's lifetime income, we measure a person's success in life as capacity to pay taxes. We further assume that neither a child, nor a parent, can borrow against future income. By contrast, the government can borrow against future tax revenue.

The problem has the following time structure. At date 1, couple $i$ takes an action, $b^{i}$, that will condition the probability distribution of the number of births. We interpret this action as reproductive activity. At date 2 , the number of children born to couple $i, n^{i}$, is revealed to all concerned. Couple $i$ then takes another action, $a^{i}$, that will condition the probability distribution of their children's future tax-paying capacity, $x^{i}$. We interpret this second action as education in the broadest sense. At date 3, a child's tax paying capacity is revealed. Parents choose $a^{i}$ and $b^{i}$ taking government policy as given. The policy consists of a general income tax, and two transfers, $s^{i}$ and $y^{i}$. The first transfer is payable at date 2 . The second is a per-child subsidy payable at date 3 . Assuming that all future citizens will make a positive tax contribution, both transfers can be taken to be nonnegative. The government chooses the $s^{i}($.$) and y^{i}($.$) schedules taking the income tax as given. Both the$ government and the parents apply backward induction.

Let $C_{t}^{i}$ denote $i$ 's consumption at date $t(t=1,2,3)$. Ex-post, $i$ 's utility is determined by

$$
U^{i}=U_{1}\left(C_{1}^{i}\right)+U_{2}\left(C_{2}^{i}\right)+U_{3}\left(C_{3}^{i}\right),
$$

where $U_{t}($.$) is increasing and strictly concave. If the couple is altruistic,$ $C_{3}^{i}$ will include not only market goods, but also the income-equivalent of the utility that they derive from their children's success in life. Denote by $w\left(a^{i}\right)$ the per-child cost of action $a^{i},{ }^{5}$ and by $c\left(n^{i}\right)$ that part of the cost of $i$ 's children that does not depend on $a^{i}$. Assuming that, at date $t$, all couples have the same after-tax income, $m_{t},{ }^{6}$ the budget constraints facing couple $i$ are then

$$
\begin{gathered}
C_{1}^{i}=m_{1} \\
C_{2}^{i}=m_{2}+s^{i}-c\left(n^{i}\right)-w\left(a^{i}\right) n^{i}
\end{gathered}
$$

and

$$
C_{3}^{i}=m_{3}+\left[y^{i}+z\left(x^{i}\right)\right] n^{i} .
$$

the cost of changing type is prohibitively high.

${ }^{5}$ If the action includes investment of parental time, $w\left(a^{i}\right)$ includes an opportunity cost, and $m_{2}$ is then to be interpreted as full income.

${ }^{6}$ With more than two types, we would have said that income and social capital are uncorrelated. 
The term $z\left(x^{i}\right)$ may be interpreted either as actual money that $i$ expects to receive from each child, conditionally on the child's income, ${ }^{7}$ or as the income-equivalent of the altruistic pleasure that couple $i$ derives from a child's economic success. To ensure concavity, we take it that $c($.$) and$ $w($.$) are increasing and strictly convex (increasing marginal costs), and$ $z($.$) increasing and strictly concave. We also assume that$

$$
z\left(x^{i}\right)<x^{i}
$$

\section{Date-2 decisions}

At date 2, agent (couple) $i$ chooses how much to invest in each child's education, $a^{i}$, taking the number of children, $n^{i}$, and government policy, as given. The principal (government) decides the structure of incentives that affect an agent's choice. We index actions and outcomes pertaining to agent $i$ by the superscript $i$. Where it is important to specify that the agent is of a certain type, we indicate that by the subscript $k=A, B$. We denote by $a_{k}=\left(a_{k}^{i}\right)$, the vector of the actions taken by all agents of type $k$, and by $a=\left(a_{A}, a_{B}\right)$ the vector of the actions taken by all agents. Similar conventions are adopted with respect to all other actions and outcomes.

The outcome, $x^{i}$, depends on an action, $a^{i}$, known only to $i$, and on a random variable, $\theta^{i}$ (fortune, genetic inheritance), with given density. The realization of $\theta^{i}$ is not observable, but its density function is common knowledge. We assume that the elements of $\theta$ are independently distributed. Following Mirrlees (1974), we treat $x^{i}$ itself as a random variable, with density $f^{i}\left(x^{i}, a^{i}\right)$. We assume that the support of $x^{i}$ is the same for all $i$, and that the density function is the same for all the agents of the same type. The joint density $f(x, a)$ is then equal to $\prod_{i} f^{i}\left(x^{i}, a^{i}\right)$.

We measure $x^{i}$ as the present value, at date 2 , of the taxes that each of $i^{\prime}$ s children will pay in adult life. The action $a^{i}$ is so defined, that the cumulative distribution of $x^{i}$ associated with a higher value of $a^{i}$ firstorder stochastically dominates the one associated with a lower value of the same variable. We assume that the likelihood ratio $\left(\frac{f_{a^{i}}^{i}\left(x^{i}, a^{i}\right)}{f^{i}\left(x^{i}, a^{i}\right)}\right)$ is increasing in $x^{i}$, and that the cumulative distribution of $x^{i}$ is convex in $a^{i}$. These conditions justify using the first-order conditions derived from the agent's decision problem as incentive-compatibility constraints in the present multi-agent setting. ${ }^{8}$

\footnotetext{
${ }^{7}$ Cigno $(1993,2005)$ derives conditions under which it is in the interest of nonaltruistic adults to make such payments to their elderly parents.

${ }^{8}$ These are the standard Monotone Likelihood Ratio and Convexity of the Distribution Function conditions that allow one to use the first-order approach in a single
} 
Let $X^{i}$ denote the set of possible outcomes for agent $i$, and $X$ the Cartesian product of all the $X^{i}$ sets. Similarly, let $X_{A}^{i}$ and $X_{B}^{i}$ denote the sets of possible outcomes for agents of type $A$ and $B$ respectively (but remember that the set is the same for both types). We assume that, if $i$ is of type $A$, and $j$ of type $B$, the marginal distribution of $x^{i}$ first-order stochastically dominates that of $x^{j}$. In other words, for any given $a_{A}^{i}=a_{B}^{j}$, the probability that $x_{A}^{i}$ is no less than a certain value, is always higher than the probability that $x_{B}^{j}$ is no less than that same value.

The assumption that, on average, one type is more productive than the other does not necessarily imply that, for any given level of the action, the expected marginal product of the action is higher for an $A$ than for a $B$ type,

$$
\int_{X^{A}} x_{A}^{i} f_{a_{A}^{i}}^{i}\left(x^{i}, a^{i}\right) d x>\int_{X^{B}} x_{B}^{j} f_{a_{B}^{j}}^{i}\left(x^{j}, a^{j}\right) d x,
$$

but we assume that to be the case nonetheless. This is equivalent to saying that, for any given $a_{A}^{i}=a_{B}^{j}$ and $\theta_{A}^{i}=\theta_{B}^{j}$,

$$
\frac{d x_{A}^{i}}{d a_{A}^{i}}>\frac{d x_{B}^{j}}{d a_{B}^{j}} .
$$

\subsection{Agents}

Couple $i$ 's expected utility is given by

$$
W_{2}^{i}=U_{2}\left(C_{2}^{i}\right)+\int_{X} U_{3}\left(C_{3}^{i}\right) f(x, a) d x,
$$

where $C_{2}^{i}$ is determined by (3), and $C_{3}^{i}$ by (4). Let $n^{-i}$ be a vector, each element of which represents the number of children born to agents other than $i$, so that $n=\left(n^{i}, n^{-i}\right)$. At this stage, couples are distinguished only by type and number of children, both of which are observable by government. The date-3 per-child government transfer payable to couple $i, y_{k}\left(x^{i} ; n^{i}, n^{-i}\right)$, will depend on $i$ 's type $(k=A, B)$, and on how many children $i$ and everyone else has. It may also be conditional on $x^{i} .{ }^{9}$ Anticipating a result that will be obtained when we examine date-1

agent setting. Luporini (2004) establishes general conditions for the applicability of that approach in a multi-agent context. Given the assumption that the random variables are independent, MLR and CDF ensure that those conditions are satisfied.

${ }^{9}$ In principle it could be conditional on the entire vector $x$, but we know from Holmström (1982) that independence of the random variables implies that the compensation is a function of one's own outcome. This will also be our result in section 3.2 . 
decisions, we assume that the date- 2 transfer to agent $i$ depends on how many children $i$ and the other couples have, $s_{k}\left(n^{i}, n^{-i}\right)$.

At date 2, $i$ has already cashed $s_{k}\left(n^{i}, n^{-i}\right)$, but is yet to receive $y_{k}\left(x^{i}, n^{i}, n^{-i}\right) n^{i}$. The couple will then choose $a^{i}$ to maximize (6). The first-order condition,

$$
-w^{\prime}\left(a^{i}\right) n^{i} U_{2}^{\prime}\left(C_{2}^{i}\right)+\int_{X} U_{3}\left(C_{3}^{i}\right) f_{a^{i}}^{i} \prod_{-i} f^{j}\left(x^{j}, a^{j}\right) d x=0,
$$

tells us that the marginal cost of $a^{i}$ will be equated to the expected marginal benefit, expressed in terms of $x^{i}$.

\subsection{Principal}

Let us now look at matters from the point of view of the principal (the government). We assume that its objective function is the sum of those of the agents (the parents),

$$
W_{2}=\sum_{i}\left[U_{2}\left(C_{2}^{i}\right)+\int_{X} U_{3}\left(C_{3}^{i}\right) f(x, a) d x\right] .
$$

At date 2, the government has already chosen and announced the transfer schedules $s_{k}(.,$.$) . Since the number of children that each couple has is$ now known, couple $i$ must now be paid $s_{k}\left(n^{i}, n^{-i}\right)$. The policy problem is then to choose the date-3 transfer schedules $y_{k}\left(., n^{i}, n^{-i}\right)$.

Having assumed that the number of agents of each type (hence, the total number of future tax payers) is "large", we may write the intertemporal government budget constraint in expected tax revenue terms as

$$
\sum_{i} \int_{X}\left[x^{i}-y_{i}\left(x^{i}, n^{i}, n^{-i}\right)\right] n^{i} f(x, a) d x \geq \sum_{i} s_{i}\left(n^{i}, n^{-i}\right),
$$

where $s_{i}(, .$.$) and y_{i}(., .,$.$) are to be interpreted as the transfer schedules$ applicable to an agent of $i$ 's type $(A$ or $B$ ) at, respectively, date 2 and date $3 .^{10}$

This constraint says that the expected tax revenue from future tax payers, $\sum_{i} \int_{X} x^{i} n^{i} f(x, a) d x$, must be large enough to cover both the expected value of the transfers that the government is promising to make at date $3, \sum_{i} \int_{X} y^{i}\left(x^{i}, n^{i}, n^{-i}\right) n^{i} f(x, a) d x$, and the actual value of the transfers that the government is committed to pay at date $2, \sum_{i} s^{i}\left(n^{i}, n^{-i}\right)$. The child generation is thus required to finance both types of transfer to

\footnotetext{
${ }^{10}$ That avoids us summing first over agents of the same type, and then over types.
} 
the parent generation. In the same way, the parent generation will have been required to pay for transfers to the grandparent generation. In a sense, therefore, the government acts as an intergenerational intermediary.

Couple $i$ take into account the effect of their action on their children's future earning ability only insofar and inasmuch as it affects the couple's own utility via $z($.$) . Being one of many, the couple has in fact$ no reason to take into account the effect of $a^{i}$ on the government budget constraint. We have thus a positive externality. Since $a^{i}$ is not observable, the government will then make the date-3 transfer conditional on the outcome, $x^{i}$.

The date-2 policy problem is to choose the transfer schedules, $y_{A}\left(., n^{i}, n^{-i}\right)$ and $y_{B}\left(., n^{i}, n^{-i}\right)$, so as to maximize (8), subject to the government budget constraint (9), and to an incentive-compatibility constraint (7) for each agent. There is no need for participation constraints because, with the number of children given, agents cannot escape the government scheme by deciding not to have children. ${ }^{11}$ Being a parameter in the principal's budget constraint, the fertility vector $n$ is also a parameter in the transfer schedule $y_{k}\left(., n^{i}, n^{-i}\right)$, and a determinant of the vector of actions $a$. We can thus write $a^{i}(n)$ for the chosen value of $a^{i}$.

The first-order conditions on the choice of the $y_{A}$ and $y_{B}$ schedules tell us that, for each possible realization of $x$, the per-child transfer to couple $i$ must satisfy

$$
U_{3}^{\prime}\left(C_{3}^{i}\right) n^{i} f^{i}-\lambda n^{i} f^{i}+\mu^{i} U_{3}^{\prime}\left(C_{3}^{i}\right) f_{a^{i}}^{i}=0,
$$

where $\lambda$ is the Lagrange-multiplier of the government budget constraint, measuring the marginal social utility of expected tax revenue, and $\mu^{i}$ the Lagrange-multiplier of the $i$-th incentive-compatibility constraint, measuring the marginal social utility of relaxing this constraint.

Using (7), we can write the first-order conditions on the choice of $a^{i}$ as

$$
D^{i}+\lambda E^{i}+\mu^{i} F^{i}=0
$$

where

$$
D^{i} \equiv-w^{\prime}\left(a^{i}\right) n^{i} U_{2}^{\prime}\left(C_{2}^{i}\right)+\int_{X} U_{3}^{\prime}\left(C_{3}^{i}\right) f_{a^{i}}^{i} \prod_{-i} f^{j}\left(x^{j}, a^{j}\right) d x
$$

\footnotetext{
${ }^{11}$ Another way the agents could avoid participating in the government scheme is by voting it (or the government that proposes it) down. However, the presence of a positive externality ensures that the median agent will have higher utility with, than without the policy. Therefore, the participation constraints will not be binding in any case.
} 
is the effect of this variable on $i$ 's expected utility and

$E^{i} \equiv \int_{X}\left[\left(x^{i}-y_{k}\left(x^{i}, n^{i}, n^{-i}\right)\right) n^{i}+\sum_{-i}\left(x^{j}-y_{j}\left(x^{j}, n^{i}, n^{-i}\right)\right) n^{j}\right] f_{a^{i}}^{i} \prod_{-i} f^{j}\left(x^{j}, a^{j}\right) d x$

the effect on the government budget constraint (the externality), ${ }^{12}$ If, as we will find in section 3.2.1 and 3.2.2, $y_{j}\left(x^{j}, n^{i}, n^{-i}\right)$ does not depend on $x^{i}$, the above expression reduces to

$$
E^{i} \equiv \int_{X^{i}}\left[\left(x^{i}-y_{k}\left(x^{i}, n^{i}, n^{-i}\right)\right) n^{i}\right] f_{a^{i}}^{i} d x^{i}
$$

in view of $\int_{X^{-i}} \prod_{-i} f^{j}\left(x^{j}, a^{j}\right) d x^{j}=1$ and $\int_{X^{i}} f_{a^{i}}^{i} d x^{i}=0$.

$F^{i} \equiv\left[w^{\prime}\left(a^{i}\right) n^{i}\right]^{2} U_{2}^{\prime \prime}\left(C_{2}^{i}\right)-w^{\prime \prime}\left(a^{i}\right) n^{i} U_{2}^{\prime}\left(C_{2}^{i}\right)+\int_{X} U_{3}\left(C_{3}^{i}\right) f_{a^{i} a^{i}}^{i} \prod_{-i} f^{j}\left(x^{j}, a^{j}\right) d x$

is the effect on $i$ 's incentive-compatibility constraint (negative for the agent's second-order conditions).

\subsubsection{First best}

Suppose, for a moment, that the principal can observe parental actions, a. Under this assumption, the incentive-compatibility constraints are not binding $\left(\mu^{i}=\mu^{j}=0\right)$. As (10) reduces to

$$
U_{3}^{\prime}=\lambda
$$

date-3 consumption is then equalized across agents and states of nature. Therefore, the first-best solution achieves perfect equity, and provides parents with full insurance. The latter is a common first-best property. In the standard principal-agent problem, however, the property arises from the assumption that the principal is less risk-averse than the agent. Here, by contrast, the principal is as risk-averse as any (maximizes the sum of the utility functions) of the agents. The result arises, in our case, from the fact that the principal is able to spread risks, while individual agents on their own cannot.

A first best can be implemented by choosing the payment schedules $y_{k}\left(., n^{i}, n^{-i}\right)$ so that every agent has the same per-child surplus,

$$
y_{k}\left(x^{i} ; n^{i}, n^{-i}\right)+z\left(x^{i}\right)=\text { const. }
$$

\footnotetext{
${ }^{12}$ Here, $y_{j}\left(x, n^{j}, n^{-j}\right)$ is to be interpreted as the transfer to an agent of $j$ 's type $(A$ or $B)$ who had $n^{j}$ children.
} 
As this implies that date-3 transfers do not depend on type, we may write the amount due to agent $i$ as $y^{*}\left(x^{i} ; n^{i}, n^{-i}\right)$.

In this setting, (11) reduces to

$$
D^{i}+\lambda E^{i}=0
$$

Since

$$
\int_{X} f d x=\int_{X^{-i}} \prod_{-i} f^{j}\left(x^{j}, a^{j}\right) d x^{j}=1 \text { and } \int_{X^{i}} f_{a^{i}}^{i} d x^{i}=0
$$

the finding that $U_{3}^{\prime}$ must be equal to $\lambda$, and that $\left(x^{j}-y_{j}\left(x^{j}, n^{j}, n^{-j}\right)\right)$ is constant with respect to $f_{a^{i}}^{i}$, allow us to re-write (18) as

$$
w^{\prime}\left(a^{i}\right) n^{i} U_{2}^{\prime}\left(C_{2}^{i}\right)=U_{3}^{\prime}\left(C_{3}^{i}\right) \int_{X^{i}}\left[\left(x^{i}-y_{k}\left(x^{i}, n^{i}, n^{-i}\right)\right) n^{i}\right] f_{a^{i}}^{i} d x^{i}
$$

which simplifies to

$$
w^{\prime}\left(a^{i}\right) U_{2}^{\prime}\left(C_{2}^{i}\right)=U_{3}^{\prime}\left(C_{3}^{i}\right) \int_{X^{i}}\left[x^{i}+z\left(x^{i}\right)\right] f_{a^{i}}^{i} d x^{i}
$$

in view of (17). This tells us that, for each agent $i$, the marginal cost of the action has to be equated to the expected marginal social benefit.

In the next section, we shall find that the first-best $U_{2}^{\prime}\left(C_{2}^{i}\right)$ is independent of $n^{i}$. Anticipating that result, and given that $U_{3}^{\prime}$ is equal to $\lambda$, we deduce from (19) that, for any given fertility vector $n$, the first-best action is the same for all agents of the same type, irrespective of how many children they themselves happen to have, and larger for agents of type $A$ than for agents of type $B$. In other words, better connected parents must invest more in the education of each child that they happen to have. Denoting by $a_{k}^{*}(n)$ the first-best action of a type- $k$ agent, we can then write

$$
a_{A}^{*}(n)>a_{B}^{*}(n) .
$$

Notice that the level of the per-child educational investment required of any couple depends on the total number of children, and on how many of these children were born to type- $A$ couples. Since the government's future revenue increases with the number of future tax payers, and with the proportion of these tax payers who enjoy a high income, it then follows that the relative importance of the future tax contribution made by each couple's children will vary inversely with the share in this total of children born to type- $A$ couples.

On the other hand, the higher the tax revenue, the higher the transfer, and the lower consequently $U_{3}^{\prime}\left(C_{3}^{i}\right)$ for each $i$. Since the left-hand 
side of (19) is increasing, and the right-hand side decreasing in $a^{i}$, the first-best level of that variable is then a decreasing function of government revenue. It thus follows that, the greater the proportion of children born to well connected parents, the lower the level of the educational investment required of each couple. This also implies that, other things being equal, $a_{k}^{*}\left(n^{i}, n^{-i}\right)$ will be decreasing in $n^{i}$ if $i$ has a high level of social capital $(k=A)$, increasing if $i$ has a low level of social capital $(k=B)$.

Let us see what we can say about the direction of the redistribution. Consider first the case where parents have no direct interest in the economic success of their children, $z\left(x^{i}\right) \equiv 0$. In the absence of policy, all parents would then have the same utility. Yet, (17) tells us that all couples get the same transfer irrespective of type, and of their children's success in life. The first-best subsidy thus re-distributes in favour of parents with lower social capital, in the sense that these parents receive more (and those with higher social capital receive correspondingly less) in subsidies than the actuarial value of the taxes that their children are expected to pay. Why?

The reason is simply that children from type- $A$ families generate, on average, more tax revenue than children with type- $B$ backgrounds. Since the combination of a Benthamite social welfare function with a concave utility function implies that marginal utilities are equalized across individuals and states of nature, it then follows that everybody must get the same per-child subsidy. Parents with low social capital will thus get out of the system more than they (or, rather, their children) put in. This differentiates ours from most optimal taxation models, where first-best redistribution is generally in favour of households or individuals with lower laissez-faire utility.

Now, suppose that parents have a direct interest in their children's future, $z^{\prime}\left(x^{i}\right)>0$. There is then an additional reason why a couple might be subsidized, namely to insure them against the risk that their children will be unsuccessful. The optimal per-child transfer to couple $i$ will thus be inversely related to the realization of $x^{i}$, not for incentive reasons (we are assuming that $a^{i}$ is observable), but to compensate them of the psychic or monetary loss from having an unsuccessful child. As a consequence, it will still be true that the first-best policy re-distributes in favour of parents with lower social capital. Indeed, it will redistribute more than if parents did not care about their children's future. But, there will now be also some within-type redistribution in favour of unlucky parents. 


\subsubsection{Second best}

Let us now go back to the more realistic assumption that the actions taken by the parents are not observable by the government. The policy must then satisfy the incentive-compatibility constraints. Since $D^{i}$ is now zero, because the incentive-compatibility constraint is binding, (11) tells us that the second-best policy induces $i$ to invest time and money in each child's education up to the point where the incentive cost, $\mu^{i} F^{i}$, is just compensated by the external effect (the welfare increase due to the additional tax revenue), $\lambda E^{i}$, generated by the induced increase in $a^{i}$. Given $n^{i}, a^{i}$ is thus higher in first than in second best. In first best, $a_{A}\left(n^{i}, n^{-i}\right)$ was higher than $a_{B}\left(n^{i}, n^{-i}\right)$. That is mostly, but not always, the case in second best too. If it costs the government less to give the incentive to the $B$ than to the $A$ type, ${ }^{13}$ the second-best policy may induce well connected parents to choose a lower level of educational investment than the rest. If the opposite is true, however, $a_{k}\left(n^{i}, n^{-i}\right)$ will be decreasing in the proportion of children born to parents with high social capital. This again implies that, other things being equal, $a_{k}\left(n^{i}, n^{-i}\right)$ should be decreasing in $n^{i}$ for $k=A$, increasing in $n^{i}$ for $k=B$.

Let us see what we can say about the second-best choice of policy instruments. As in first best, the government's future tax revenue increases with the number of future tax payers, and with the proportion of them who enjoy a high income. The per-child transfer due to $i$ will thus depend on the entire $n$ vector. As in first best, it will increase with the proportion of children who were born to parents with high social capital. Since parental investments are not observable, it will depend also on $x^{i}$. How?

Considering that $\mu^{i}$ is now positive, we re-write (10) as

$$
\frac{\lambda}{U_{3}^{\prime}\left(C_{3}^{i}\right)}=1+\frac{\mu^{i}}{n^{i}} \frac{f_{a^{i}}^{i}\left(x^{i}, a^{i}\right)}{f^{i}\left(x^{i}, a^{i}\right)},
$$

where, it should be remembered, $\frac{f_{a^{i}}^{i}}{f^{i}}$ is increasing in $x^{i}$ and varies according to $i^{\prime}$ s type. We have seen that, in first best, the date-3 transfer schedule is the same for everyone. We have also seen that the per-child transfer due to $i$ varies with $x^{i}$ only if the latter is of direct interest to $i$. In second-best, by contrast, there is a different schedule for each type, reflecting the different cost of giving a couple with high or low social capital the incentive to invest in their children's education. Furthermore,

\footnotetext{
${ }^{13}$ The trade-off between productivity and incentive costs is examined in Kim (1995), and Robbins and Sarath (1996).
} 
since $\lambda$ is positive at an optimum, (21) tells us that agent $i$ 's second-best utility will vary with $x^{i}$ even if $z\left(x^{i}\right) \equiv 0$.

If parents have no direct interest in their children's success, $y_{k}\left(x^{i}, n^{i}, n^{-i}\right)$ increases with $x^{i}$. In that case, parents are rewarded in direct relation to how well their children have done in adult life. Matters are more complicated if parents have a direct interest in their children's success in life. Since (21) implies that the per-child benefit to couple $i$,

$$
z\left(x^{i}\right)+y_{k}\left(x^{i}, n^{i}, n^{-i}\right),
$$

is increasing in $x^{i}$, it follows from concavity of $z($.$) that y_{k}\left(x^{i}, n^{i}, n^{-i}\right)$ may be increasing or decreasing in $x^{i}$. Since $z^{\prime}\left(x^{i}\right)$ is positive, and decreasing in $x^{i}$, the schedule is then likely to be U-shaped. Concerned parents of either very unsuccessful or very successful children will likely attract higher transfers - the former for insurance, the latter for incentive reasons - than concerned parents of children of middling ability.

Notice that the difference between $y_{A}\left(x^{i}, n^{i}, n^{-i}\right)$ and $y_{B}\left(x^{i}, n^{i}, n^{-i}\right)$ is only due to the need to satisfy (21). Apart from that, utility will still tend to be equalized across types, because $\lambda$ is the same for both. This tells us that the need to provide parents with the incentive to invest in their children's education reduces the scope for redistributing from parents with high, to parents with low social capital. If giving the incentive to the former is no more costly than giving it to the latter, some redistribution will still take place, but full equity will not be reached.

\section{Date 1}

Let the number of children born at date 2 to couple $i, n^{i}$, depend on the couple's reproductive activity at date $1, b^{i}$, and on a random variable, $\zeta^{i}$. In recognition of the fact that $n^{i}$ is a discrete variable, we write its density, the same for all agents, as $p\left(n^{i}, b^{i}\right)$. Obviously, the $\zeta^{i}$ and, consequently, the $n^{i}$ are independently distributed. We can then write the joint density as

$$
P(n, b)=\prod_{i} p\left(n^{i}, b^{i}\right)
$$

We interpret $b^{i}$ as something (e.g., frequency of intercourse) that increases the chances of having a large number of children. We thus assume that the cumulative distribution of $n^{i}$ associated with a higher value of $b^{i}$ first-order stochastically dominates the one associated with a lower value of the same variable.

We also assume that $p\left(n^{i}, b^{i}\right)$ satisfies the standard Monotone Like-

lihood Ratio $\left(\frac{p_{b^{i}}\left(n^{i}, b^{i}\right)}{p\left(n^{i}, b^{i}\right)}\right.$ increasing in $\left.b^{i}\right)$, and Convexity of Distribution Function, conditions. Among other things, these assumptions ensure the 
concavity of the agent's expected utility with respect to $b^{i}$ (see footnote 8 above). Since, at this stage, agents differ only in their social capital endowment, agents of the same type behave the same. That is not true at date 2 , where agents are differentiated also by number of children.

\subsection{Agents}

We saw in the last section that, at date 2 , a $k$-type couple chooses $a^{i}$ taking $n^{i}, s_{k}\left(n^{i}, n^{-i}\right)$ and $y_{k}\left(., n^{i}, n^{-i}\right)$ as given. Since the government choice of $y_{k}\left(x^{i}, n^{i}, n^{-i}\right)$, takes into account the vector of actual date-2 transfers, $s\left(n^{i}, n^{-i}\right)$, i's date-2 choice is ultimately a function of how many children they, and all other couples, happen to have. At date 1 , couple $i$ does not know how many children will be born at the date 2 , nor what $y_{k}\left(x^{i}, n^{i}, n^{-i}\right)$ is going to be. All they know is the date-2 transfer schedule, $s_{k}\left(n^{i}, n^{-i}\right)$. We shall assume that they hold rational expectations about everyone else's decisions.

At date 1 , couple $i$ will then choose $b^{i}$ to maximize

$$
W_{1}^{i}=U_{1}\left(C_{1}^{i}\right)+\sum_{N^{i}} P(n, b)\left[U_{2}\left(C_{2}^{i}\right)+v^{i}\left(a^{i}\left(n^{i}, n^{-i}, s(n)\right)\right)\right],
$$

where the operator $\sum_{N}$ indicates a string of summations, one for each agent. The term $v^{i}\left(a^{i}(n, s(n))\right)$ represents the maximum value of $(6)$, given the realization of $n$. In other words, $v^{i}\left(a^{i}(n, s(n))\right)$ is the expectation at date 1 of the couple's utility at date 3 , on the assumption that, at date 2 , the couple will have chosen $a^{i}$ optimally, given government policy and the number of children actually born.

The first-order condition for the maximization of $(22)$ is

$$
\sum_{n^{i}} p_{b^{i}}\left(n^{i}, b^{i}\right) \sum_{N^{-i}} \prod_{N^{-i}} p\left(n^{j}, b^{j}\right)\left[U_{2}\left(C_{2}^{i}\right)+v^{i}\left(a^{i}(n, s(n))\right)\right]=0,
$$

where the operator $\prod_{N^{-i}}$ indicates a string of products, one for each agent other than $i$. Condition (23) tells us that each couple will raise their level of reproductive activity to the point where the expected marginal utility equals the current marginal cost. The latter is zero for the assumption that, unlike educational investment, reproductive activity costs nothing in itself. ${ }^{14}$ There are, however, expected costs (reflected in $C_{2}^{i}$ via $\left.c\left(n^{i}\right)\right)$ arising from the possible realizations of $n^{i}$.

\footnotetext{
${ }^{14}$ That is not true in the case of infertile couples, for whom reproductive activity involves either expensive and perhaps unpleasant medical practices, or long and costly adoption procedures. But nothing of substance changes if we make the marginal cost of $i$ 's reproductive activity an increasing function of $b^{i}$.
} 


\subsection{Principal}

The government's date-1 budget constraint is

$\sum_{i} \sum_{N} P(n, b) s_{i}\left(n^{i}, n^{-i}\right) \leq \sum_{i} \sum_{N} P(n, b) \int_{X}\left[x^{i}-y_{i}\left(x^{i}, n^{i}, n^{-i}\right)\right] n^{i} f(x, a) d x$.

This differs from (9) in three respects. ${ }^{15}$ First, because $n^{i}$ and $n^{-i}$ are still random variables. Second, because the $s_{k}(.,$.$) schedules are yet to be$ determined. Third, because the $y_{k}\left(., n^{i}, n^{-i}\right)$ schedules are determined (as part of the solution of the date-2 policy problem).

The government chooses the date- 2 transfer schedules, $s_{k}(.,$.$) , so as$ to maximize

$$
W_{1}=\sum_{i}\left[U_{1}\left(C_{1}^{i}\right)+\sum_{N} P(n, b)\left[U_{2}\left(C_{2}^{i}\right)+v^{i}\left(a^{i}\left(n^{i}, n^{-i}, s(n)\right)\right)\right],\right.
$$

subject to (24), and to an incentive compatibility constraint (23) on the choice of $b^{i}$ for each $i{ }^{16}$ Since, at date 1 , all agents of the same type behave the same, the incentive compatibility constraint is the same for all agents of the same type. That is also the reason why there are only two date-2 transfer schedules, one for each type of couple.

As pointed out in subsection 4.1, the $s_{k}(.,$.$) schedules must be an-$ nounced before the agents choose their reproductive behaviour. At date $2, i$ will in fact bear a cost, $c\left(n^{i}\right)$, that increases with the number of children. In the absence of a transfer increasing with $n^{i}$, the couple would then choose, at date 1 , too low a level of reproductive activity, because they would not take into account the effect of their behaviour on the government budget constraint. We have thus another externality, similar to the one encountered at date 2 . The latter concerned the choice of $a$, given $n$, and was cured offering $i$ a transfer conditional on the realization of $x^{i}$. The present one concerns the choice of $b$, and is cured by promising each $i$ a transfer conditional on the realization of $n^{i}$.

The first-order condition on the government's choice of $s_{k}(.,$.$) is$

$$
p\left(n^{i}, b^{i}\right)\left[U_{2}^{\prime}\left(C_{2}^{i}\right)-v\right]+\gamma^{i} U_{2}^{\prime}\left(C_{2}^{i}\right) p_{b^{i}}=0
$$

\footnotetext{
${ }^{15}$ Once again, $s_{i}\left(n^{i}, n^{-i}\right)$ and $y_{i}\left(x, n^{i}, n^{-i}\right)$ are to be interpreted as the transfer schedules applicable to agents of $i$ 's type.

${ }^{16}$ At this stage, there is no need for participation constraints because the externality argument guarantees that the expected utility of both types of agent is higher than it would be in the absence of the policy. No one will then opt out by not having children.
} 
where $\gamma^{i}$ is the Lagrange-multiplier of the incentive-compatibility constraint for agent $i,(23)$, and $v$ the Lagrange-multiplier of the date-1 government budget constraint, (24). We can re-write (26) in the more convenient form

$$
\frac{v}{U_{2}^{\prime}\left(C_{2}^{i}\right)}=1+\gamma^{i} \frac{p_{b^{i}}\left(n^{i}, b^{i}\right)}{p\left(n^{i}, b^{i}\right)} .
$$

If either $b$ or the realizations of $\zeta$ were observable, we would have a first-best solution. As $\gamma^{i}$ would then be equal to zero, (27) would reduce to

$$
U_{2}^{\prime}\left(C_{2}^{i}\right)=v
$$

The first-best policy thus assures parents a given level of date- 2 consumption, independent of how many children they actually have. The date-2 transfer $s_{k}^{*}\left(n^{i}, n^{-i}\right)$, increasing in $n^{i}$, fully insures parents against the risk of having too few, or too many, children.

Now, recall that $a_{k}^{*}(n)$ is a determinant of $C_{2}^{i}$, and that $s_{k}^{*}\left(n^{i}, n^{-i}\right)$ is thus dependent on the whole fertility vector, $n$. Recall, also, that $a_{A}^{*}(n)$ is greater than $a_{B}^{*}(n)$ in view of (20). If $n^{i}=n^{j}=n^{o}$, where $i$ is an agent of type $A$, and $j$ an agent of type $B$, it then follows that

$$
s_{A}^{*}\left(n^{o}, n^{-i}\right)>s_{B}^{*}\left(n^{o}, n^{-j}\right) .
$$

This says that, in first best, a couple with more social capital will receive a higher date-2 subsidy than a couple with the same number of children, but lower social capital.

Since the actions are not observable, however, we have a moral hazard problem. In second best, $\gamma^{i}$ is positive for each $i$. Having assumed that $\frac{p_{b^{i}}\left(n^{i}, b^{i}\right)}{p\left(n^{i}, b^{i}\right)}$ is increasing in $n^{i}$, and given that $U_{2}^{\prime}\left(C_{2}^{i}\right)$ is decreasing in $C_{2}^{i}$, it then follows from (27) that $C_{2}^{i}$ must increase with $n^{i}$. We can see from (3) that the direct effect of $n^{i}$ on $C_{2}^{i}$ is negative, but there is also an indirect effect via $a^{i}$. The second-best $a^{i}$ are increasing in $n^{i}$ for $B$ types and decreasing for $A$ types. This implies that $s_{B}\left(n^{i}, n^{-i}\right)$ is always increasing in $n^{i}$, while $s_{A}\left(n^{i}, n^{-i}\right)$ may be decreasing if the indirect effect of $n^{i}$ on $C_{2}^{i}$ dominates the direct effect. The second-best $s_{A}\left(n^{i}, n^{-i}\right)$ is thus likely to be increasing in $n^{i}$ at low family sizes, where $C_{2}^{i}$ is low, but may flatten out or start to decrease above a certain level of $n^{i}$. In other words, the government may want to discourage type- $A$ parents from having children above a certain maximum. That is not needed in the case of type- $B$ parents, because the date- 2 incentive to invest in a child's education is not strong enough for this type of parent to induce them to have too many children. The question obviously does not arise in first best, where behaviour is observable, and parents can thus be ordered 
to undertake the socially optimal level of reproductive activity (we have already remarked on this distasteful implication of observability).

The first-order conditions on the principal's choice of $b$ are not very enlightening. All we can deduce from them is that, in first best, parents endowed with more social capital will be required to have more children. That is not necessarily true in second best, however, because it may cost the government too much to give parents with high social capital the right incentives to invest in their children's education. It is just possible, therefore, that it will not be worthwhile to encourage type- $A$ parents with large social capital endowments to have many children.

\section{Discussion}

We have examined a situation where potential parents can condition (i) the probability distribution of having $0,1,2 \ldots$ children through their choice of reproductive activity, and (ii) the probability distribution of their children's future earning ability through their choice of educational investment. We are assuming that the amount a child will pay in taxes increases with the child's future earning ability. We are also assuming that, for any given amount of parental money and time spent on a child's upbringing, children of well connected parents have a higher probability of landing a good job, and of advancing in their career, than children with less favourable family backgrounds.

We have identified three motives for government intervention. The first motive arises from the presence of two externalities, one associated with reproductive behaviour, the other with educational investment. Both externalities reflect the fact that atomistic couples have no reason to take into account the effects of their decisions on future government revenue. The second motive arises from insurance considerations. Since parents face risks in relation to the number of children that is born, and to the success that each of these children will have in future life, while the government does not face any risk in relation to its future revenue (because the total number of children is large), social welfare may increase if the government insures parents. The third is an equity motive. If they have a direct interest in their children's future, parents endowed with lower social capital have lower expected utility, in the absence of policy, than couples endowed with higher social capital.

If parental actions were observable, the government would do two things. First, it would order couples to undertake the first-best level of reproductive activity, and the first-best level of educational investment in each child that is born. The required level of both actions would be higher for couples with high, than for couples with low social capital. Second, it would use personalized lump-sum transfers to equalize mar- 
ginal utilities. The policy would thus achieve perfect equity. If parents care about what will happen to their children in adult life, the policy would achieve also full insurance.

In reality, however, parental actions are not observable, and cannot be inferred from fertility and tax paying outcomes, because these are in part the result of chance. As a consequence, the government can neither tell a couple what to do in the bedroom, nor order them to devote a certain amount of money and time to the education of their offspring. As the government must give parents the incentive to behave efficiently on both scores, the second-best policy will then achieve neither perfect equity, nor full insurance. The second-best policy uses two instruments.

One is a subsidy, $s_{k}\left(n^{i}, n^{-i}\right)$, payable as soon as $i$ 's children are born. For parents with low social capital, the size of this subsidy is everywhere increasing in $n^{i}$. For parents with high social capital, by contrast, it may be increasing up to a certain level of $n^{i}$, and constant or decreasing beyond that. In other words, it may be desirable to discourage better connected parents from having too many children. Such a disincentive is not needed in the case of less well connected parents, because those will be discouraged by increasing educational costs. We may interpret this side of the policy as a child benefit scheme.

The other instrument is a per-child transfer, $y_{k}\left(x^{i}, n^{i}, n^{-i}\right)$, payable as soon as the tax paying capacity of $i$ 's children is revealed. Taking it to be the norm that parents have a direct interest in their children's future, the size of this transfer is likely to be decreasing in $x^{i}$ up to a certain point, and then increasing. Parents with children of normal ability are thus likely to get less help from the government than parents of children with either very low, or very high ability. To the extent that school performance is a predictor of a child's future earning ability, we may interpret $y_{k}\left(x^{i}, n^{i}, n^{-i}\right)$ as a scholarship. Alternatively, since the tax paying capacity of a couple's children will become known only when the latter are in middle life, and the former on the point of retirement, we may interpret $y_{k}\left(x^{i}, n^{i}, n^{-i}\right) n^{i}$ as the present value of $i^{\prime}$ s pension entitlement.

Take the second interpretation. Although the money received by currently retired citizens comes out of taxes paid by current workers, this is not a conventional pay-as-you-go scheme. In the latter, the taxes paid by current adults go into a common pool, and the pension that an old person receives bears no relation to the tax-paying capacity of that person's children. As a consequence, the scheme does not give current workers an incentive to produce future tax payers. Indeed, if pension entitlements are related to own tax payments, it is an incentive to have fewer children, and to invest as little time as possible in each of them. 
Here, by contrast, there is a direct relationship between the payment that a retired person receives, and the taxes paid by that person's own children. ${ }^{17}$ We can think of this as either an alternative to a conventional pension scheme, or an addition such that a working-age person has the choice of qualifying for a pension by either paying pension contributions, or producing future tax payers.

Social capital affects the expected social return to educational investment. If parents care for what will happen to their children in adult life, it affects also the expected private return. The second-best policy implications of differences in social capital endowments are not straightforward, because the policy maker must balance efficiency with equity and insurance considerations, and compare the cost of providing an incentive with the external effect of the resulting action. We find that, other things being equal, the second-best policy redistributes in favour of couples with lower social capital. Nonetheless, it generally encourages better connected parents to have more children than less well connected ones. Notice that the latter is not what happens in practice. In real-life family support schemes, benefits are either unrelated to parental characteristics (depend only on number of children), or favour families with lower social capital. That is dangerous, because it may encourage couples (and single mothers) with lower social capital to have more children than the rest, and thus to increase rather than decrease the number of underprivileged children.

Our results suggest that couples with low social capital should be helped, as far as possible, using policy instruments that act as an incentive to invest in a child's future achievements, rather than in number of children. Cigno and Pettini (2002) reach the same conclusion in an indirect taxation framework. In the present framework, the incentive comes either from scholarships, contingent on a child's scholastic achievement, or pension entitlements, contingent on the children's labour market achievements. In either case, the "merit" element is tempered by equity and insurance considerations. ${ }^{18}$ Parents, however, cannot wait for the scholarship - even less for the pension - to arrive before they start to invest in their children's education. That is why parents must get the other transfer as soon as the child is born.

\footnotetext{
${ }^{17}$ For redistributive and insurance reasons, however, the pension may be larger or smaller than the taxes paid by the pensioner couple's children.

${ }^{18}$ This makes a transfer system financed by a general income tax superior to indirect taxation, but the latter may be cheaper to administer.
} 


\section{References}

Balestrino, A., A. Cigno and A. Pettini (2002), Endogenous Fertility and the Design of Family Taxation, International Tax and Public Finance 9, 175-193

Broome, J. (1993), The Value of Living, Recherches Economiques de Louvain 58, 125-142

Cigno, A. (1993), Intergenerational Transfers without Altruism: Family, Market and State, European Journal of Political Economy 9, 505-518 (2005), The Political Economy of Intergenerational Cooperation, in S. Kolm and J. Mercier-Ythier (eds.), Handbook of Giving, Reciprocity and Altruism (Handbooks in Economics Series, edited by K. J. Arrow and M. D. Intriligator), Amsterdam: North-Holland

- A. Luporini, and A. Pettini (2003), Transfers to Families with Children as a Principal-Agent Problem, Journal of Public Economics 87, 1165-1177

, A. Luporini, and A. Pettini (2004), Hidden Information Problems in the Design of Family Allowances, Journal of Population Economics 17, 645-655

- and A. Pettini (2002), Taxing Family Size and Subsidizing Child-Specific Commodities?, Journal of Public Economics 84, 75-90

Cremer, H., A. Dellis and P. Pestieau (2003), Family Size and Optimal Income Taxation, Journal of Population Economics 16, 37-54

—, F. Gahvari and P. Pestieau (2003), Pay-as-you-go Pensions with Endogenous and Stochastic Fertility, Paper to the 2003 CESifo Venice Summer Institute

Durlauf, S. (2001), The Membership Theory of Poverty: the Role of Group Affiliations in Determining Socio-Economic Outcomes, in S. Dazinger and R. Haveman (eds.), Understanding Poverty, Cambridge, Mass.: Harvard University Press

Eckstein, Z. and K. I. Wolpin (1985), Endogenous fertility and Optimum Population Size, Journal of Public Economics 27, 93-106

Granovetter, M. (1995), Getting a Job: A Study of Contacts and Careers, 2nd Edition, Chicago, University of Chicago Press

Holmström, B. (1982), Moral Hazard in Teams, Bell Journal of Economics $13,324-340$

Kim, S. K. (1995), Efficiency of an Information System in an Agency Model, Econometrica, 63, 89-102

Luporini, A, (2004), Relative Performance Evaluation in a MultiPlant Firm, Economic Theory (forth.)

Michel, Ph. and P. Pestieau (1993), Population Growth and Optimality. When Does Serendipity Hold?, Journal of Population Economics 6, 353-362 
Mirrlees, J. A. (1974), Notes on Welfare Economics, Information and Uncertainty, in M. S. Balch, D. L. McFadden and S. Y. Wu (eds.) Essays on Economic Behavior and Uncertainty, Amsterdam: North-Holland

Peters, W. (1995), Public Pensions, Family Allowances and Endogenous Demographic Change, Journal of Population Economics 8, 161-183

Razin, A. and E. Sadka (1995), Population Economics, Cambridge Mass.: MIT Press

Robbins, E. H. and B. Sarath (1998), Ranking Agencies under Moral Hazard, Economic Theory, 11, 129-155

Sinn, H.-W. (2004), The Pay-As-You-Go Pension System as Fertility Insurance and Enforcement Device, Journal of Public Economics 88, $1335-1357$

Stigler, G. (1962), Information in the Labor Market, Journal of Political Economy 70, 94-105 


\section{CESifo Working Paper Series}

(for full list see www.cesifo-group.de)

1601 Jan K. Brueckner, Fiscal Federalism and Economic Growth, November 2005

1602 Steven Brakman, Harry Garretsen and Charles van Marrewijk, Cross-Border Mergers and Acquisitions: On Revealed Comparative Advantage and Merger Waves, November 2005

1603 Erkki Koskela and Rune Stenbacka, Product Market Competition, Profit Sharing and Equilibrium Unemployment, November 2005

1604 Lutz Hendricks, How Important is Discount Rate Heterogeneity for Wealth Inequality?, November 2005

1605 Kathleen M. Day and Stanley L. Winer, Policy-induced Internal Migration: An Empirical Investigation of the Canadian Case, November 2005

1606 Paul De Grauwe and Cláudia Costa Storti, Is Monetary Policy in the Eurozone less Effective than in the US?, November 2005

1607 Per Engström and Bertil Holmlund, Worker Absenteeism in Search Equilibrium, November 2005

1608 Daniele Checchi and Cecilia García-Peñalosa, Labour Market Institutions and the Personal Distribution of Income in the OECD, November 2005

1609 Kai A. Konrad and Wolfgang Leininger, The Generalized Stackelberg Equilibrium of the All-Pay Auction with Complete Information, November 2005

1610 Monika Buetler and Federica Teppa, Should you Take a Lump-Sum or Annuitize? Results from Swiss Pension Funds, November 2005

1611 Alexander W. Cappelen, Astri D. Hole, Erik Ø. Sørensen and Bertil Tungodden, The Pluralism of Fairness Ideals: An Experimental Approach, December 2005

1612 Jack Mintz and Alfons J. Weichenrieder, Taxation and the Financial Structure of German Outbound FDI, December 2005

1613 Rosanne Altshuler and Harry Grubert, The Three Parties in the Race to the Bottom: Host Governments, Home Governments and Multinational Companies, December 2005

1614 Chi-Yung (Eric) Ng and John Whalley, Visas and Work Permits: Possible Global Negotiating Initiatives, December 2005

1615 Jon H. Fiva, New Evidence on Fiscal Decentralization and the Size of Government, December 2005 
1616 Andzelika Lorentowicz, Dalia Marin and Alexander Raubold, Is Human Capital Losing from Outsourcing? Evidence for Austria and Poland, December 2005

1617 Aleksander Berentsen, Gabriele Camera and Christopher Waller, Money, Credit and Banking, December 2005

1618 Egil Matsen, Tommy Sveen and Ragnar Torvik, Savers, Spenders and Fiscal Policy in a Small Open Economy, December 2005

1619 Laszlo Goerke and Markus Pannenberg, Severance Pay and the Shadow of the Law: Evidence for West Germany, December 2005

1620 Michael Hoel, Concerns for Equity and the Optimal Co-Payments for Publicly Provided Health Care, December 2005

1621 Edward Castronova, On the Research Value of Large Games: Natural Experiments in Norrath and Camelot, December 2005

1622 Annette Alstadsæter, Ann-Sofie Kolm and Birthe Larsen, Tax Effects, Search Unemployment, and the Choice of Educational Type, December 2005

1623 Vesa Kanniainen, Seppo Kari and Jouko Ylä-Liedenpohja, Nordic Dual Income Taxation of Entrepreneurs, December 2005

1624 Lars-Erik Borge and Linn Renée Naper, Efficiency Potential and Efficiency Variation in Norwegian Lower Secondary Schools, December 2005

1625 Sam Bucovetsky and Andreas Haufler, Tax Competition when Firms Choose their Organizational Form: Should Tax Loopholes for Multinationals be Closed?, December 2005

1626 Silke Uebelmesser, To go or not to go: Emigration from Germany, December 2005

1627 Geir Haakon Bjertnæs, Income Taxation, Tuition Subsidies, and Choice of Occupation: Implications for Production Efficiency, December 2005

1628 Justina A. V. Fischer, Do Institutions of Direct Democracy Tame the Leviathan? Swiss Evidence on the Structure of Expenditure for Public Education, December 2005

1629 Torberg Falch and Bjarne Strøm, Wage Bargaining and Political Strength in the Public Sector, December 2005

1630 Hartmut Egger, Peter Egger, Josef Falkinger and Volker Grossmann, International Capital Market Integration, Educational Choice and Economic Growth, December 2005

1631 Alexander Haupt, The Evolution of Public Spending on Higher Education in a Democracy, December 2005

1632 Alessandro Cigno, The Political Economy of Intergenerational Cooperation, December 2005 
1633 Michiel Evers, Ruud A. de Mooij and Daniel J. van Vuuren, What Explains the Variation in Estimates of Labour Supply Elasticities?, December 2005

1634 Matthias Wrede, Health Values, Preference Inconsistency, and Insurance Demand, December 2005

1635 Hans Jarle Kind, Marko Koethenbuerger and Guttorm Schjelderup, Do Consumers Buy Less of a Taxed Good?, December 2005

1636 Michael McBride and Stergios Skaperdas, Explaining Conflict in Low-Income Countries: Incomplete Contracting in the Shadow of the Future, December 2005

1637 Alfons J. Weichenrieder and Oliver Busch, Artificial Time Inconsistency as a Remedy for the Race to the Bottom, December 2005

1638 Aleksander Berentsen and Christopher Waller, Optimal Stabilization Policy with Flexible Prices, December 2005

1639 Panu Poutvaara and Mikael Priks, Violent Groups and Police Tactics: Should Tear Gas Make Crime Preventers Cry?, December 2005

1640 Yin-Wong Cheung and Kon S. Lai, A Reappraisal of the Border Effect on Relative Price Volatility, January 2006

1641 Stefan Bach, Giacomo Corneo and Viktor Steiner, Top Incomes and Top Taxes in Germany, January 2006

1642 Johann K. Brunner and Susanne Pech, Optimum Taxation of Life Annuities, January 2006

1643 Naércio Aquino Menezes Filho, Marc-Andreas Muendler and Garey Ramey, The Structure of Worker Compensation in Brazil, with a Comparison to France and the United States, January 2006

1644 Konstantinos Angelopoulos, Apostolis Philippopoulos and Vanghelis Vassilatos, RentSeeking Competition from State Coffers: A Calibrated DSGE Model of the Euro Area, January 2006

1645 Burkhard Heer and Bernd Suessmuth, The Savings-Inflation Puzzle, January 2006

1646 J. Stephen Ferris, Soo-Bin Park and Stanley L. Winer, Political Competition and Convergence to Fundamentals: With Application to the Political Business Cycle and the Size of Government, January 2006

$1647 \mathrm{Yu}-\mathrm{Fu}$ Chen, Michael Funke and Kadri Männasoo, Extracting Leading Indicators of Bank Fragility from Market Prices - Estonia Focus, January 2006

1648 Panu Poutvaara, On Human Capital Formation with Exit Options: Comment and New Results, January 2006 
1649 Anders Forslund, Nils Gottfries and Andreas Westermark, Real and Nominal Wage Adjustment in Open Economies, January 2006

1650 M. Hashem Pesaran, Davide Pettenuzzo and Allan G. Timmermann, Learning, Structural Instability and Present Value Calculations, January 2006

1651 Markku Lanne and Helmut Luetkepohl, Structural Vector Autoregressions with Nonnormal Residuals, January 2006

1652 Helge Berger, Jakob de Haan and Jan-Egbert Sturm, Does Money Matter in the ECB Strategy? New Evidence Based on ECB Communication, January 2006

1653 Axel Dreher and Friedrich Schneider, Corruption and the Shadow Economy: An Empirical Analysis, January 2006

1654 Stefan Brandauer and Florian Englmaier, A Model of Strategic Delegation in Contests between Groups, January 2006

1655 Jan Zápal and Ondřej Schneider, What are their Words Worth? Political Plans and Economic Pains of Fiscal Consolidations in New EU Member States, January 2006

1656 Thiess Buettner, Sebastian Hauptmeier and Robert Schwager, Efficient Revenue Sharing and Upper Level Governments: Theory and Application to Germany, January 2006

1657 Daniel Haile, Abdolkarim Sadrieh and Harrie A. A. Verbon, Cross-Racial Envy and Underinvestment in South Africa, February 2006

1658 Frode Meland and Odd Rune Straume, Outsourcing in Contests, February 2006

1659 M. Hashem Pesaran and Ron Smith, Macroeconometric Modelling with a Global Perspective, February 2006

1660 Alexander F. Wagner and Friedrich Schneider, Satisfaction with Democracy and the Environment in Western Europe - a Panel Analysis, February 2006

1661 Ben J. Heijdra and Jenny E. Ligthart, Fiscal Policy, Monopolistic Competition, and Finite Lives, February 2006

1662 Ludger Woessmann, Public-Private Partnership and Schooling Outcomes across Countries, February 2006

1663 Topi Miettinen and Panu Poutvaara, Political Parties and Network Formation, February 2006

1664 Alessandro Cigno and Annalisa Luporini, Optimal Policy Towards Families with Different Amounts of Social Capital, in the Presence of Asymmetric Information and Stochastic Fertility, February 2006 